\title{
Handicraft Tourism in Pokhara: Connecting the Past Tradition to the Present
}

\author{
Prakash Upadhyay, $\mathrm{PhD}^{*}$
}

\begin{abstract}
Although the importance of handicraft has been widely recognized, the literature regarding the role of handicraft in tourism market is scarce. Based on empirical data, the present article aimed to explore the interplay between handicraft and tourism, the contribution of handicraft in tourism promotion and the challenges faced by handicraft sector in Pokhara, Nepal. This study identifies that there is a significant level of correlation and dependency between handicraft and foreign tourist arrivals, job creation and the increase in income and social status of handicraft shop proprietor. As a harbinger of past tradition, handicraft tourism/souvenir items has created a unique experience for tourist, enriched nation's pride, belief and identity and connected the past tradition to the present. Lack of effective advertisement/marketing, inequitable price, scarcity of raw materials, intrusion of foreign goods, ineffective government policies are the key challenges of handicraft tourism. Policy improvement, increase in source/supply of raw materials, supply of handicrafts as per demand, creative production and marketing are the ways that can promote handicraft market. Handicraft tourism is not just about displaying and selling products, it is about allowing tourists to truly understand the skill/craft at rear and realize handicrafts unique tradition, linking tourists to artisans to facilitate them understand and appreciate the art. It is necessary recognizing the importance of local handicraft in sustainable tourism development and the importance of tourism as an agent for protection and preservation of traditional crafts, methods of production and cultural milieu.
\end{abstract}

Keywords: Marketing, souvenir consumer, tourism, traditional handicraft.

\section{INTRODUCTION}

The term tourist denotes an individual who travels for a desire or curiosity with social, cultural and economic pursuits. Bhatia (1982) argue that human kind has always had the desire to travel to visit exotic place and encounter different cultures. UNWTO (2008) defines tourism as a social, cultural and economic phenomenon which entails the movement of people to countries or places outside their usual environment for personal or business/professional purposes. For Kunwar (2002), tourists are temporary visitors staying at least 24 hours in country visited with a purpose. The most significant aspect of tourism is its economic dimensions. Tourism is inspirable part of the development programs and also such other problems like unemployment, social and regional disparities (Punia, 1997). Mill and Morris (1985) said that other than approaching tourism sector as a tool for development of the whole economy of or country, it brings some economic benefits for the settlements. It is also useful to develop the other sectors of the economy viz. agriculture, fishing, poultry farming, dairy farms, and handicraft industries. Increase in the number of tourists insist more service in tourism industry, and hence, create more employment

Dr. Upadhyay is Associate Professor of Anthropology, Tribhuvan University, Prithvi Narayan Campus, Pokhara Email:prak-socio@hotmail.com 
opportunities and finally enrich the national economy. Furthermore as a social phenomenon, tourism promotes socio-cultural exchange and brings different people to the proximity, thereby dispelling the mendacious mysticism or romanticism.

Tourism is not merely a business, but a medium by which people may discern and understand one another and each other's socio-cultural life style, traditions, belief systems, art, architecture and gather experience on local cultures. Cultural tourism includes the quaint of indigenous peoples vanishing life styles that lies within human reminiscence with its old styles houses, cultural fabrics, hand-made skills rather than machine made crafts. Destination activities include meals in native style, folklore performances, customs and festivals, art and architecture. The term heritage and cultural tourism refers to that segment of tourism industry that places special emphasis on heritage and cultural attractions which are varied, and include performances, museums, displays, archaeological sites and the like (Smith, Macleod, \& Robertson, 2010; Fernandes, 2013). Heritage and cultural attractions may include traditional religious practices, handicraft and cultural performances. DeKadt (1979) emphasized that cultural tourism would be even more important in small countries. Smith (1989) opined cultural tourism as the absorption by tourists of features resembling the vanishing life style of past societies observed through such phenomena as house styles, handicraft, farming equipment and dress. Through these cultural aspects of tourism people learn each other's ways of life and thought. Personal international contact is a vital way of understanding other cultures. Ritchie and Zins (1978) argue that cultural tourism is an element in the attractiveness of tourism regions. They isolated twelve elements of culture which attract tourists to particular destinations viz. handicraft, language, tradition, gastronomy, art and music concerts paintings and sculpture, history, work and technology, architecture, religion, educational system, dress, leisure activities all drawing on specific aspects of destination area. Discussions on cultural tourism have mainly focused on specific area, including remote regions of developed and developing countries like Nepal, Thailand etc (McKean, 1989). For Cohen (1972) research emphasis on such areas may reflect a narrow view of the nature of indigenous culture and stereotyping of native.

In the recent days, the tourism literature began to widen the discussion to include aspects of culture and heritage in urban areas. At the same time a significant tool of cultural tourism is a growing phenomenon of culture, or heritage interpretation. Lea (1988) presents three major forms of culture, which attract visitors--forms of cultures, which are inanimate or which do not directly involve human activities, tourist visiting places of unique architecture and art, historical buildings, monuments, and purchasing traditional arts and crafts. Embedded with culture, cultural tourism experiences handicraft as representing local tradition and indigenous populations, symbolizes the place visited by tourists, their experiences, and a souvenir to be taken for friends and relatives. Besides evoking wonderful memories by tourists when taking a good quality handicraft home, it arouses the interest of others who see it to visit the destination (UNWTO, 2018). Handcrafted objects as tangible components and craftsmanship as being intangible in culture are among the resources mobilized in tourism. Exploiting these resources for tourism purposes is of a great significance to sustainable development. Mustafa (2011) argue that such significance comes from the fact that manufacturing traditional artistic objects generates both income and employment opportunities. Further, there is a natural link between handcrafts and tourism as these two are inextricably connected, with mutual advantage in building and promoting one sector to support the other.

Shakya (2017) stated that in Nepal's cultural history, handicraft has been a skill that has been handed down through the generations and a major source of income for artisans. It is a living heritage and 
handicraft serve religious and utilitarian purposes. Today, tourism business thrives with the export and selling of handicraft products ranging from metal statues of gods to woolen carpets. But despite the ability and skills of Nepali craftsmen, the handicraft sector has not been explored for its full potential in tourism market. While traditional handicraft can be seen displayed in shops and showrooms in major tourist hot spots, very few actually promote the process of producing such items and the stories of craftsmen behind it and very little is known on the interplay between handicraft and tourism market and the embedded challenges. Vijayagopalan (1993) said that the importance of handicraft is both cultural and economic. The cultural importance of handicraft leads to the preservation of the heritage, traditional skills and the art. Its economic importance lies in high employment potential, low capital investment, high value addition, and potential for export/foreign exchange earnings. Ramamurthy (1996) believed that handicraft is not the commodities of sale rather they possess a religious and spiritual appeal. Handicraft are the hand creation from dexterous fingers of the craftsmen which are self expressive in their natural form, revealing a conscious aesthetic beauty approach and are reviewed as an essential segment of cultural heritage tourism. Since Nepal is known for its traditional art and culture, Nepalese handicraft isn't only extra-ordinarily artful but also depicts the Nepalese culture and conventions. It is through tourism that handicraft products of Nepal can get recognition in the international market. Therefore, the scope of handicraft tourism seems incredible in Pokhara which is a tourism hub of Nepal. Moreover, it preserves the culture and artisans and utilizes the local resources. Pokhara can serve a great variety of tourist needs for understanding Nepali tradition, culture, art and architecture. Particularly indigenous handicraft can be used in tourism for future prospective like demonstration of cultural prosperity, indigenous traditional technology etc.

\section{THEORETICAL PERSPECTIVES ON TOURISM}

Tourism is relevant to many theoretical and real-world issues in many disciplines including anthropology. The major themes anthropologists have covered in the study of tourism may be divided conceptually into two categories: one that seeks to understand the origins of tourism, and the other reveals tourism's impacts. The problem is that most studies aimed at understanding the origins of tourism tend to focus on tourists, and most research concerning the impacts of tourism tend to focus on locals and in the process many issues of culture, tradition, heritages, ecology etc remain unstudied. Greenwood (1989) argued that tourism has also been studied by anthropologists as a form of cultural commoditization and/or cultural commercialism ....culture is packaged, priced, and sold like building lots. As the tourism industry extends its grasp commoditization of local peoples' culture results in them being exploited. Contrary, Cohen (1988) and McKean (1989) perceive Greenwood's notion of exploitation as an over-generalization. The impact of commoditization on the meaning and authenticity of cultural products, should not just be assumed to be destructive, but should be looked at within an emic, processual, and comparative framework (Cohen 1988). Cohen's argument is that the emergence of a tourist market frequently facilitates the preservation of a cultural tradition which would otherwise perish casts commoditization in a positive light which is contrary to Greenwood's repugnant claim.

Ensuring the benefit for the local population, emphasis to conservation efforts and involvement of the communities to respect and protect their fragile historical and cultural heritages are the issues to be dealt with in order to achieve prosperity of society. Often, social and cultural aspects of a host area are seen as synonyms. Mathieson and Wall (1982) stated that alternatively, cultural attributes (and impacts) may be 
regarded as a sub-set of social conditions. Archeological and historical places, distinctive architectural styles, social dance, music, drama, ceremonies, arts and crafts, dress, customs and value systems comprise the culture of an area that offers attraction for tourists and can either be selectively conserved and enhanced by tourism or degraded by it, depending on how tourism is involved and managed.

\section{PROBLEM AND OBJECTIVE}

Barber, Dalziel, Derks, and Kula, (2006), assert that the benefits derived by handicraft shop proprietors from the sales of handicraft to tourists in many developing countries are insufficiently researched. Despite the importance of handicrafts, the literature regarding the role of handicraft in tourism market is meager. Further very little literature has revealed the contribution of this industry to people's livelihood. For this reason, there may have been an underestimation of the importance of the tourism informal handicraft sector in eradicating poverty and empowering the poor (Chhabra, Healy, \& Sills, 2003). The cultural products like handicraft have greatly contributed to the development of tourism sector and have been helpful in creating jobs and publicizing Nepalese culture. However, the excessive focus on the natural beauty of Pokhara, landscape and trekking has overshadowed the contribution of cultural assets and products. Though a number of studies (Adhikari, 2010; Upadhyaya, 2003) have been accomplished in this field, there has been very little anthropological research that has analyzed the contribution of handicrafts in promoting tourism in Lakeside, Pokhara. Further, various studies have shown benefits at country level, but botched to show the challenges specifically for people engaged in the selling of handicraft products. This current study attempts to look at the market level to gain an indepth understanding of the real benefits derived by handicraft entrepreneurs so as to conclude logically at small scale level and avoid the fallacy of generalization. Given this, the key objective of this article is to analyze the interplay between handicraft and tourism especially the contribution of handicraft in the promotion of tourism and the challenges of handicraft business in Pokhara.

\section{DATA AND METHODS}

This study was conducted in Lakeside, a popular tourism hub, situated in the south-western part of Pokhara metropolitan city of Kaski district, Nepal. Handicraft tourism is one of the important contributing factors for the promotion of tourism in Lakeside. Handicrafts are important cultural products and due to the availability of a large variety of handicraft items, Lakeside is best suited for understanding the ways in which the handicraft business contributes in promoting tourism in a specific place. The universe of this study comprised of the handicraft shops of Lakeside area (altogether 204 handicraft shops). At first, they were numbered in order to prepare a sampling frame and out of the total 204 handicraft shops, only 106 shops were sampled following systematic random sampling on the ground that owing to similar professional milieu and location, there is more commonality and representativeness of populations exhibiting a natural degree of randomness.

Primary data was congregated through semi-structured interviews with 106 handicraft shop proprietors. Additionally, case study, observation and key informant interviews (altogether 3) were accomplished in gathering primary information. Two members of Pokhara Handicraft Association and one social activist were the key informants. The key informants were selected on the principles that most members of any society do not know the full repertory of forms, meanings and functions of their society 
as claimed by Sjoberg and Nett (1968). As such, key informants, as a result of their personal skills/ position within the local society, are able to provide in-depth information and a deeper insight into what was going on around them. For controlling the validity and reliability, a generic assessment checklist was designed on the magnitude of handicraft and its role in tourism market and pre-test was consummated on fifteen handicraft shops of Lakeside that assisted in maintaining consistency of reliability across time, items and respondents. This facilitated in assisting validation of measurement tools so that to represent the variables they are intended to. Ethical approval in the form of verbal consent was obtained from each respondent (handicraft shop proprietor) before administering the interview and they were convinced of the confidentiality of their identity. The field study was conducted during September 21 to October 19, 2019.

\section{RESULTS AND DISCUSSION}

While Nepal is conducting Visit Nepal Year 2020 campaign aiming to bring two million tourists by 2020, the international tourists arrival in Nepal in 2018 was 1,173,072, a growth of $+24.8 \%$ compared to the previous year. About one million tourists (both foreign and domestic) visited Pokhara in 2018, and among them, 60 percent were Nepalese (The Kathmandu Post, 2019). Pokhara is largely known for city tourism orientation due to natural beauty, cultural attractions, handicraft, social cohesion, harmony and mutual respect. It is famous for hospitality and adventure tourism. Presence of different ethic/caste groups has made Pokhara valley an attractive place from cultural point of view that offers a number of joyful activities based on nature, culture, tradition, heritage, ceremony, adventure, and sports (NTB, 2011).

Handicraft tourism is a prominent form of tourism attraction and a source of occupation for many. Most of the handicraft shop proprietors of Lakeside i.e. 39.6 percent are from the age group 26-35 years followed by 30.2 percent from the age group 36-45. Likewise, 19.8 percent are from the age group 16-25 years. Besides, 7.6 percent are above 45 years and 2.8 percent from 56 and above age group. In a predominantly patriarchal Nepalese society, majority of proprietors i.e. 80.2 percent are male and rest 19.8 percent are female. Around 5.9 percent are illiterate, 31.1 percent are just literate, while 30.2 percent are 2/PCL passed, 21.7 percent are Bachelor Level passed, and 7.6 percent are Master Level passed. Broadly the educational status of proprietors was reasonably better with more than half with a qualification equivalent to or above PCL/+2 level. Majority of the proprietors are Brahmin and Kashmiri Muslim i.e. 24.5 percent each, 13.2 percent are Chhetri and 8.5 percent were Tibetans. Besides, they are from Tamang, Dalit, and Gurung community. Most i.e. 50.0 percent are Hindus, whereas 22.6 percent are Buddhists and 24.5 percent are Muslims. Around 54.7 percent of them are living in an extended family and the rest 45.3 percent are living in a nuclear family.

\subsection{Souvenir Consumer and Contribution in Tourism Promotion}

Handicraft shops are widely visited by shopping tourists. Timothy (2005) assumed that shopping tourism by souvenir consumers is the most favored travel activities and has supported tourism growth and revenue contribution. Around 94.3 percent handicraft shops at Lakeside have been visited by foreign tourists as souvenir customers, while 34.0 percent are internal tourists from different parts of Nepal. Similarly, 3.8 percent are the local visitors from Pokhara. 
Table 1

Souvenir Customer

\begin{tabular}{lrr}
\hline Type of the Customers & Number & Percent \\
\hline External (foreign) tourists & 100 & 94.3 \\
Internal (domestic) and foreign tourists & 36 & 34.0 \\
Local, internal and foreign tourists & 4 & 3.8 \\
\hline Total & $140^{*}$ & \\
\hline
\end{tabular}

*Multiple responses

Source: Field survey, 2019

Foreign tourists are the recurrent and major customers of handicraft shops of Lakeside. One case reveals the charisma of souvenir handicraft items for foreign tourist.

\section{Case I}

Videsi haru hamra mukhya grahak hoon (Foreigners are our main customers)

As a handicraft shop proprietor, I have experienced that souvenirs and tourism are allied since souvenirs represent an object purchased to remind the buyer of experience or destination visited. Foreign tourists often purchase souvenirs either for themselves or as a gift to someone back at home. Among the handicraft souvenir items purchased by foreign tourists are local craft, postcards, fine art, pottery, woodcarvings and figurines, baskets, blankets, clothing, fabrics. Nepali people are little aware of the worth and uniqueness of these items.

Indigenous cultural souvenirs has facilitated familiarize Nepalese handicraft items globally, popularizing Pokhara as a popular touristic destination, magnetizing tourists as well publicizing the country as a brand ambassador, hence thereby promoting the identity of Nepal colossally. The case below divulges the viability of souvenir handicraft in tourism promotion.

Case II

Hastakala ra videshi paryatak antarnirvar chan (Handicraft and foreign tourist are interdependent) Many foreign tourists arrive merely to buy indigenous handicrafts which create jobs and lead to the increase in our/artisans income and social status. Handicraft and foreign tourist are mutually dependent. Tourism is not possible without handicraft; also handicraft can't thrive without tourist. If the Government provides easy access of raw materials, skilled employees, cut-low the taxes, we will be able to produce quality goods. It definitely, will help attracting more tourists as well as help in publicizing Nepal at international level.

Due to the expansion of tourism industry and escalating worth of handmade products, the demand of the handicraft has greatly increased which has boosted tourist arrival that signifies the correlation between the handicraft and the foreign tourist arrival. Further, there is the dependency of the handicraft industry on the tourist arrivals. Hence, it is crucial recognizing the magnitude of local handicraft in tourism development and reciprocally the magnitude of tourism as an agent for the protection and preservation of traditional crafts, methods of production and the cultural context.

Kim (1997) states that favorable attitude toward the aesthetic and the uniqueness of souvenirs indicates significant direct effects on purchase intention of the souvenir. It is the exclusivity of souvenir artifacts that appeal customers' intent to purchase that item. Based on artifacts attraction types, the items 
appealing and purchase intent of souvenir handicrafts at Lakeside can be categorized into three types as cultural items, items related to art and religion. For 51.9 percent tourists visiting Lakeside, cultural products are the major attractions, while for 41.5 percent artistic items are the main attraction. Similarly, for 6.6 percent tourist, religious items are the chief attractions.

Almost all visitors buy at least one handicraft item in their visit to Lakeside. There are various advantages of handmade crafts and products viz. reusability of waste materials, indigenous creativity and skills, self-employment, eco-friendly, local identity and uniqueness. Tourists considered handicrafts that can be displayed at home that makes a good gift, and are handmade as the most appealing attributes for handicrafts. Foreign tourists deem handmade items viz. garments as naïve, indigenous, more natural, healthy and easy to wear. The researcher observed many foreign tourists wearing handmade garments along with different indigenous handicraft items. When asked about the price of handicraft, most of the tourists did not find them costly.

\subsection{Employment Generation and Alteration in Lifestyle}

Jansen-Verbeke (1998) assumes that the retail trade of souvenirs has always been part of the tourism experience and contributes to the local economy and employment in many tourism destination areas. Around 64.2 percent handicraft shops at Lakeside have provided employment to family members, rest 35.8 percent have provided employment to other people outside the family. There were a total of 376 employees working in 106 handicraft shops. Out of them 210 are the family members and rest 166 are from outside the family.

Table 2

Employment Generation through Handicraft

\begin{tabular}{lcc}
\hline \multicolumn{1}{c}{ Response } & Number & Jobs Provided \\
\hline Employment only for family members & $68(64.2)$ & $210(55.9)$ \\
Employment outside the family & $32(35.8)$ & $166(44.1)$ \\
\hline Total & $106(100.0)$ & $376(100.0)$ \\
\hline
\end{tabular}

Source: Field survey, 2019

In average, a shop was generating about 3.5 job opportunities. It is largely due to the handicraft tourism that these shops have been able to provide such number of jobs. One case elaborates.

\section{Case III}

Hastakala le nokari srijana gareko cha (Handicraft has assisted in creating jobs)

I am a Kashmiri Muslim running this business with the support of my wife and her relatives. I have four employees. Handicraft business is risky but good for earning money and for giving jobs. Handicrafts help to promote tourism, generate employment as well as facilitates in tourist arrivals. There is a link between tourist arrival and our income and the handicraft production. Because of them there has been an increase in our and artisans income. We need to boost-up handicraft production of different items and maintain the fair price rate of products for the sake of whole tourism industry.

There is a close association between the tourist arrivals and the increase in the income levels of handicraft entrepreneurs. There is an intricate relationship between the tourism industry, proprietor 
and the handicraft production. Handicrafts are the source of income; it has led to substantial and multifaceted alterations in handicraft proprietors' lifestyle/livelihood pattern. The changes have taken place in various aspects of individual life that includes day-to-day fooding pattern, clothing style, housing pattern, consumption of market goods, schooling of children etc. Handicraft shop proprietors perceived the alteration in their social status after they got involved in handicraft business. Around 81.1 percent labeled an escalation in their social status after the adoption of handicraft business. They perceived their social status much better compared to the period before they got involved in this business. They got due admiration during social gatherings or meetings. One of the key-informant interviewee put forward that the handicraft proprietors have firmly established themselves in the local society; as a result mutual reverence has greatly increased among the people. Since most of them are experiencing certain degree of rise in their social status, they are blissful and satisfied with handicraft business. With the increasing satisfaction, they have increased their investment in the diversification, expansion and further promotion of handicraft business which has consequently facilitated in the promotion of Lakeside tourism.

\subsection{Marketing and Supply of Handicraft Items}

In any kind of business, marketing plays very important factor for product promotion. Around 53.8 percent handicraft proprietors market their business/items within Pokhara, 2.8 percent of them market their items at national level. Importantly, 41.5 percent market their items internationally.

Table 3

Marketing of Handicraft Products

\begin{tabular}{|c|c|c|}
\hline Response & Number & Percent \\
\hline Pokhara only & 57 & 53.8 \\
\hline National level & 3 & 2.8 \\
\hline International & 44 & 41.5 \\
\hline No response & 2 & 1.9 \\
\hline Total & 106 & 100.0 \\
\hline
\end{tabular}

Source: Field survey, 2019

The marketing of handicraft products at national level is bleak due to the lack of publicity at a mass level. Further, proprietors have less trust over national media. However, the marketing of the handicraft items at the international level has been done by a significant number of proprietors as well as by Nepal Tourism Board. One case divulge in detail.

\section{Case IV}

Hastakala ko thorai bajarikaran vayeko cha (There has been less marketing of handicraft)

Previously 40 to 50 thousand rupees was enough to initiate this business, but now 4 to 5 Lakh rupees is required. The quantity of sale is affected by the season. We face difficulty in importing raw materials, the government charges heavy tax. Handicraft product makes our identity abroad. We should maintain similar price rates; do adequate marketing of our products at national/international levels. There has been inadequate marketing of handicraft items not only at worldwide level but even at the national level.

When the demand of any market items increases, ensuring its efficient supply becomes a challenging task. The researcher attempted to find the state of supply of handicraft items (especially those preferred 
by tourist). For 55.7 percent proprietors, the supply of handicraft items is good, while for 0.9 percent the supply is not in accordance to the demand of tourist. For them the handicraft products are not being produced as per the market demand. They stressed on appropriate actions on the part of concerned agencies to work towards availing the handicraft items as per the demands of tourist.

Table 4

Supply of Handicraft Items at Shops

\begin{tabular}{lrr}
\hline State of supply of handicraft items & Number & Percent \\
\hline Very good & 5 & 4.7 \\
Good & 59 & 55.7 \\
Normal & 41 & 38.7 \\
Below the demand & 1 & 0.9 \\
\hline Total & 106 & 100.0 \\
\hline
\end{tabular}

Source: Field survey, 2019

Fulfillment of foreign tourists demand plays an important role in promoting handicraft tourism at international level. For 63.2 percent proprietor, the supply of handicraft items is meeting the demand of their international customers. Their international consumers do not go discontented due to the lack of handicraft items. But for 33 percent, the supply is below tourist demand and for 3.8 percent the supply is not in accordance to the demand of international customers. Further many handicraft products are not being produced as per the market demand of foreign customers. Difficulty in access of raw materials is also a serious concern. For 68.9 percent proprietor, their handicrafts have been manufactured using the locally available raw material products, while for 31.1 percent, their handicrafts are manufactured from the imported raw material. It was noticed that many handicraft shop had employed artisans manufacturing handicrafts at the corner of the shop. Local products include all type of handicraft products made from Nepali raw materials. Since majority of handicraft proprietors rely on classier local raw material and the handicraft items made from them, price of their handicraft products is much expensive owing to the worth of products based on local raw materials.

\section{Case V}

Kachha padhartha sajilai uplavda hunu parcha (There should be easy access of raw materials)

I use Nepali raw material for making handicrafts since it is very complicated to import foreign materials. It takes long time to arrive here. If the Government provides us easy loan, raw materials, and good publicity it will help the growth of handicraft industry. We sell indigenous materials made from stone, statues of god/ goddess, bangles, pottery, basket, tatting, tapestry, garments etc. Foreigners give us good response and I am planning to manufacture goods according to customer's choice in future.

Though handicrafts have been playing a very crucial role in the promotion of tourism in Lakeside, it is not devoid of tribulations and challenges. Kumar and Rajeev (2014) stated that one of the major issues faced by handicraft sector is in information dissemination. This has led to a situation where customers have no information related to the craft products. Inefficient advertisement/marketing, intrusion of foreign goods, inadequate supply of raw materials, inappropriate market price and ineffective government policies are some of the key challenges of handicraft industry in Pokhara. About 33.0 percent 
handicraft proprietors reckon that lack of effective advertisement/marketing is the main challenge faced by handicraft sector in Lakeside, while 18.9 percent view the encroachment of foreign readymade items and inadequate supply of raw materials as the problem. Similarly, for 14.2 percent, there is the lack of appropriate market price, for 9.4 percent there is the lack of effective government policies and the rest 24.5 percent think all of the above reasons as the main hurdles.

Price variations of touristic products for internal and foreign tourists has created unfair commercial environment. Around 60.4 percent proprietors sell the similar handicraft item at different rates for foreign and domestic tourists. They charge more money to foreign tourists. Around 37 percent sell without such difference in price. When asked about the reason for this difference, almost all could not furnish concrete and rationale reason.

Around 37.7 percent proprietors deem that quality improvement will automatically contribute in promoting the handicraft business. Similarly, 33.0 percent consider increase in the source/supply of raw materials, 32.1 percent deem ensuring supply as per the demand, 17.0 percent gave priority to creative production and 30.2 percent view all of the above as the main ways for ensuring the promotion of handicraft products. Additionally, 49.1 percent deem that the future of handicraft business is bright, for 44.5 percent, it is very bright and for 6.6 percent, it is normal. It denotes that almost all of them perceive the future of handicraft business as positive and glowing. In the view of one of the key-informants, the reason for such perception is the uniqueness and the benefits of Nepalese traditional handicraft items. They are such that foreign consumers easily get attracted. For most of them they are quite unique and conventional, so they prefer to buy the handicrafts. Hand-made handicraft items viz. pottery items, weaved basket, tatting, macramé, crochet, tapestry, mosaic along with popular products like scarf, shawl and blanket are the popular choices of tourists especially the foreign tourist. Scuffling with various problems and challenges, amid traditional skills and with nominal investment, Lakeside tourism has been successful in linking the handicraft sector to the tourism market and past tradition of cultural uniqueness to its present.

\section{CONCLUSION}

There is a link between handicrafts and foreign tourist arrival and the increase in income and social status of handicraft shop proprietor. Additionally, the handicraft business is dependent on tourist arrival and job creation. With an escalation in the arrival of foreign tourists amid the charm of artistic Nepalese handicrafts as souvenir items, the income and social status of proprietor has augmented that has facilitated in providing employment to people from within and outside the family and playing a vital role in extending the fame of local artistic items at national and international level. Handicraft tourism has connected Nepal's past tradition to its present that has helped generate a unique experience for tourists leading to escalation of tourist arrival hence contributing positively to the promotion of tourism and nation's pride, belief and identity. Souvenir handicraft market has facilitated the preservation of Nepali cultural tradition which otherwise would have perished. It has led to the economic empowerment of the people involved with it and made them prideful of their hand-made handicrafts which is coherent to Cohen's (1988) theoretical argument that commoditization on the meaning and authenticity of cultural products should not just be assumed to be destructive, but should be looked at within an emic and processual framework.

Though, handicrafts have been playing a significant role in the promotion of tourism, its contribution has been made trivial owing to excessive focus on the natural beauty and landscape of Pokhara that has overshadowed the contribution of handicraft sector. As a result, handicraft tourism has not been getting sufficient attention from the concerned authorities. Hence, it's the right time for the recognition 
of handicrafts' contribution and thereby their promotion so that they play much enhanced role in the promotion of overall tourism sector of Pokhara and Nepal. It is necessary to focus on quality improvement and creative production and maintain a balance between supply and demand of handicraft products. It is indispensable to focus on production and marketing practices of handicraft and drawing lessons in relation to production technologies and design aspects, financial and management aspects of production units, marketing channels and methods for optimizing the sale of handicraft among tourist and the tourism industry. It is crucial defining strategies and practical tools for governments and the private sector to strengthen the links between handicraft production and tourism, the skill and craft of the artisan who really make it, prevent them from exploitation and becoming too commercialized, identifying the roles of the government departments and tourism organizations and the sources of financial and technical assistance.

\section{REFERENCES}

Adhikari, K. (2010). Non-performing loan and its management. New Business Age, 3(12), 22-23.

Barber, T., Dalziel, E., Derks, E., \& Kula, O. (2006). Haitian handicraft value chain analysis. Haiti: United States Agency for International Development (USAID).

Bhatia, A.K. (1982). Introduction to tourism management. New Delhi: Sterling Publication.

Cohen, E. (1972). Towards a sociology of international tourism. Social Research, 39, 164-189.

Cohen, E. (1988). Authenticity and commoditization in tourism. Annals of Tourism Research, 15(3), 371-386.

Chhabra, D., Healy, R., \& Sills, E. (2003). Stage authenticity and heritage tourism. Annals of Tourism Research, 30, 702-719.

DeKadt, E. (1979). Tourism in Cyprus: Tourism passport to development. New York: Oxford University Press. Fernandes, C. (2013). The impact of cultural tourism on host communities. In Raj, R. Griffin, K. \& Morpeth, N. (eds.) Cultural Tourism, (pp.26-38) Wallingford: Cabi International.

Greenwood, D. J. (1989). Culture by the pound: An anthropological perspective on tourism as cultural commoditization. In V. Smith (Ed.) Hosts and guests: The Anthropology of Tourism, 171-185 Philadelphia: University of Pennsylvania Press.

Jansen-Verbeke, M. (1998). The synergism between shopping and tourism. In W. F. Theobald (ed.). Global tourism: The Next Decade (2 ${ }^{\text {nd }}$ ed.). Oxford: Butterworth-Heinemann Ltd., pp. 428-446.

Kim, S. (1997). International tourists'souvenir purchasing behaviour. Ames, Iowa: Iowa State University.

Kumar, D., \& Rajeev, P.V. (2014). Marketing challenges of handicraft retailers in changing environment. ZENITH International Journal of Business Economics \& Management Research ZIJBEMR, 4(10), 22-33.

Kunwar, R.R. (2002). Anthropology of tourism: A study of Chitwan Sauraha. New Delhi: Adroit Publishers. Lea, J (1988). Tourism and development in the Third World. London: Routledge.

Mathieson, A, \& Wall, G. (1982). Tourism economic, physical and social impacts. London: Longman.

McKean, P. F. (1989). Towards a theoretical analysis of tourism. Economic dualism and cultural involution in Bali.

In V. Smith (Ed.) Hosts and Guests: The Anthropology of Tourism, 119-138.

Mill, R.C. \& Morrison, A.M. (1985). The tourism system: An introduction text. New Jersey: Prentice-Hall.

Mustafa, M. (2011). Potential of sustaining handicraft as a tourism product in Jordan. International Journal of Business and Social Science, 2(2), 145-152.

Nepal Tourism Board. (2011). Paradise Pokhara. Kathmandu: Nepal Tourism Board.

Punia, B. K. (1997). Tourism management: Problem and prospects. Delhi: Ashish Publishing House.

Ramamurthy, P.A. (1996). Handicraft-promotion under KVIC Sector. Khadigramodhyog, 42(7), 365-368.

Ritchie, J.R., \& Zins, M. (1978). Culture as determinant of the attractiveness of a tourism region. Annals of Tourism 
Research, 5(2), 252-267.

Shakya, A. (2017). Handicraft tourism: A new way to connect tourism \& tradition. New Business Age. Retrieved from https://www.newbusiness.com/MagazinesArticles/views/1880

Sjoberg G., \& Nett, R. (1968). A methodology for social research. New York: Harper and Row.

Smith, V.L. (1989). Host and guest: The anthropology of tourism. Philadelphia: University of Pennsylvania Press.

Smith, M., MacLeod, N., \& Robertson, M. H. (2010). Key concepts in tourist studies. Los Angeles: Sage.

Timothy, D.J. (2005). Shopping tourism, retailing, and leisure. Clevedon: Channel View Publication.

The Kathmandu Post (2019). 2018 brought more visitors and more money to Pokhara. Monday, September 2, 2019.

United Nations World Tourism Organization (2008). Understanding tourism: Basic glossary. Retrieved from http://media.unwto.org/en/content/understanding-tourism-basic-glossary

United Nations World Tourism Organization (2018). Report on tourism and culture synergies. Madrid: UNWTO. Upadhyaya, D.P. (2003). Handicraft, its export and design impacts. HAN, Kathmandu, p. 13.

Vijayagopalan, S. (1993). Economic status of handicraft artisans. New Delhi: National Council of Applied Economic Research. 